\title{
Contemporary Intercultural and Ethnic Views of Ukrainian Youth Student About the Poles
}

\author{
Svitlana Sysoieva /e-mail: 2099823@gmail.com \\ Academy of Educational Sciences of Ukraine, Kyiv, Ukraine
}

Natalia Dichek /e-mail: n.p.dichek@gmail.com

Institute of Pedagogy, National Academy of Educational Sciences of Ukraine, Kyiv, Ukraine

Sysoieva, S. - Dichek, N. (2020). Contemporary Intercultural and Ethnic Views of Ukrainian Youth Student About the Poles. Czech-Polish Historical and Pedagogical Journal, 12/2,132-145.

doi: $10.5817 /$ cphpj-2020-027

In the context of intensification of Europe's migration processes at the beginning of the 21st century, intercultural communication of people resulted in readjustment of traditional systems of their norms and values; new values are being shaped while traditional ones are losing their dominant status. It is deemed necessary to shape a new cross-border and multicultural identity in the younger generations in order to prepare them to life in various cultural environments. A new standard of cultural awareness is to prevent possible effects of cultural shock, minimize such negative attitudes as national and racial prejudice. The objective of the paper is to outline results of the massive survey which involved students of higher educational institutions as well as senior students of secondary education institutions in Ukraine. The survey reflects the latest ethnic and intercultural ideas (representations) and values of Ukrainian youth, in particular their attitudes to the Poles as a separate nation and a close neighbour or ethnic minority residing in Ukraine.

Key words: views or representations; intercultural; Poles; survey; Ukrainians

\section{Introduction}

Modern world is becoming more pluralistic, multicultural and changing. With the number of intercultural contacts permanently increasing the convergence of standards and values of life has become one of the distinguishing features of modern cross-cultural discourse. At the same time researchers observe an intensification of so called glocalization processes, competitive relations between countries and nations are being accompanied by the desire of most nations to preserve and protect their ethnic and cultural traditions. The process of shaping personal system of norms and values is influenced by the following factors: educational and family background, language of everyday communication, historical memory, traditions, customs and rules defined by a particular ethnic 
and social environment. Therefore, it is deemed feasible to launch the process of shaping a new cross-border and multicultural identity so that younger generation can be able to adjust to different cultural spheres, without experiencing negative effects of cultural shock, without professing chauvinism, xenophobia and other types of national prejudices.

In the context of intensification of Europe's migration processes at the beginning of the $21^{\text {st }}$ century, intercultural communication of people resulted in readjustment of traditional systems of their norms and values; new values are being shaped while traditional ones are losing their dominant status ${ }^{1}$.

In Poland, the problems of intercultural education and communication in recent decades are the subject of research of many scientists ${ }^{2}$.

In particular, a regular study of the current state and perspectives of further development of intercultural relations between Poles and residents of neighbouring countries has been conducted at the University of Silesia (Cieszyn) since 2015, as a large-scale, international study, in which a group of Ukrainian scholars have been actively involved as well. Taking into account the common border, historical context, intensification of educational interchanges, economic contacts the intercultural communication issues are important for Ukraine and Poland, which was noted by Ukrainian scientists ${ }^{3}$.

The questionnaires were developed by Polish colleagues from the University of Silesia. In Ukraine it was applied under the guidance of academician S. Sysoieva. A mass survey of Ukrainian students and senior students of secondary educational institutions (or school students) was conducted with the purpose of collecting empirical data and evaluating youth's attitude towards the Poles as a separate nation (state) and an ethnic group residing on the territory of Ukraine. Analysis of the obtained results of the survey is the subject of this article.

${ }^{1}$ Afanasieva, L. - V. Oleksenko, R. I. (2018). Pryncyp polikulturnosti yak osnova cyvilizacijnogo rozvytku suchasnogo suspilstva. [The principle of polyculturality as a basis of the civilized development of the modern society]. Aktualni problemy filosofii ta sociologii, 22. pp. 3-6. (In Ukrainian).

2 Nikitorowicz, J. (2012). Education challenges of multicultural society in the context of mythology of the Eastern borderlands. In: Edukacja w społeczeństwach wielokulturowych. Warszawa, Wyższa Szkoła Pedagogiczna ZNP Uniwersytet w Białymstoku, pp. 73-90; idem. (2010). Grupy etniczne w wielokulturowym Świecie. Sopot, Gdańskie Wydawnictwo Psychologiczne Sp. Z o.o; Lewowicki, T. (2014). Edukacja wielokulturowa i międzykulturowa - konteksty rodzime (polskie), europejskie i globalne. In: Wielokulturowość i edukacja. Warszawa-Cieszyn-Kijów, pp. 21-36.

3 Kremień, W. (2014). Innowacyjne środowisko warunkiem nowej rzeczywistości połeczno-kulturowej. In: Wielokulturowość i edukacja. Warszawa-Cieszyn-Kijów, pp. 37-44. Bakirov, V. - Ushakova, T. Khyzhniak, L., (2017). Mizhkulturna komunikaciya v universyteti: istoriya, dosvidy, vyklyky suchasnosti. [Intercultural communication at the university: history, experience, modern challenges]. Visnyk Kharkivskogo nacionalnogo universytetu imeni V. N. Karazina, vol. 39, pp. 286-293 (In Ukrainian); Sysojewa, S. (2014). Kulturologiczne problem edukacji w badaniach ukraińskichi polskich uczonych. In: Wielokulturowość i edukacja. Warszawa-Cieszyn-Kijów. pp. 22-29. 


\section{Research Methodology}

The sample of respondents was chosen based on the following considerations. First, student's and school-student's environments are high-intensity zones of intercultural interaction and inter-ethnic contacts. It is the environment of institutions of secondary and higher education where representatives of various ethnic groups encounter with various systems of world perception and worldviews. As a result of such encounters, stereotypes of intercultural perception and behaviour models are shaped in young people providing a fundament for further interaction. Therefore, the period of obtaining new knowledge and skills by the younger generations in the process of school or college education is a vital period for shaping their ethnic and intercultural self-consciousness. Secondly, within this period due to psychological factors new models of behaviour (i.e. tolerance, accepting the Other etc.) are easier to teach and incorporate in young individuals' mentality and transform them in driving factors which determine models of their intercultural interaction.

Research of the state and quality of intercultural awareness of Ukrainian University and secondary school students (regarding their abilities in perceiving another ethnic community - the Poles in particular) were based on the ideas of S. Moskovichi ${ }^{4}$ about social representations that are part of individual consciousness and represent typical group norms and values of a particular community, including ethnic. According to research methodology, it was accepted that individual's awareness and perception of other ethnic groups can be inferred and evaluated based on such parameters: self-identification (origin), level of understanding historical background, national distinguishing traits (features), geographical and territorial parameters etc. ${ }^{5}$.

The study of the current state of intercultural perceptions of Ukrainian students and senior school students was conducted in 2017 using a multiparameter questionnaire (44 questions) developed by Polish scientists. The 1325 respondents from 12 cities of different regions of Ukraine (Kyiv, Mariupol,

${ }^{4}$ Moskovichi, S. (1995). Sotsialnyie reprezentatsii: istoricheskie perspektivyi [Social representations: historical perspestectives]. Psichologicheskii zhurnal, Vol.16. pp. 13-14 (In Russian); Moscovici, S. - Markova, I. (2006). The Making of Modern Social Psychology. Cambridge, Polity Press. Also see: Kenrick D. T., Neuberg, S. L. \& Cialdini, R. B. (1999). Social Psychology: Unraveling the Mysteries. Boston, Allyn \& Bacon.

5 Deardorff, D. K. (2012). Intercultural Competence in the $21^{\text {st }}$ Century: Perspectives, Issues, Application. In: Breninger's (Ed.) Creating Cultural Synergies. Cambridge Scholars, pp. 65-79. Sknar, O. (2007). Osoblyvosti etnosotsialnykh uiavlen molodi. [The peculiarities of ethnic and social concepts of youth]. Sotsialna psykholohiia, 3. 58-66 (in Ukrainian); Sliushchynsky, B. (2016). Mizhkulturna komunykaciya yak regulyator mizhosobystisnykh vidnosyn suspilstva. [Intercultural communication as a regulator of interpersonal relationships in the society]. Nova paradygma, Vol, 130, pp. 83-98. (In Ukrainian). 
Melitopol, Zaporizhia, Rivne, Lutsk, L’viv, Chernivtsi, Kamyanets-Podilskyi, Khmelnytsky, Vinnytsya, Kremenchuk) took part in the survey: 1025 respondents $(77 \%)$ were students of high schools, 300 persons $(23 \%)-$ students of the $10^{\text {th }}$ form of secondary schools.

The survey was conducted in face-to-face format; it combined group form and individual survey. Its goal was to collect empirical data about the current general intercultural and ethnic representations of Ukrainian youth and their attitudes to the Poles.

Survey objectives:

1. To accumulate sufficient empirical data about the contemporary intercultural views or representations of Ukrainian youth in relation to the Poles.

2. To compare intercultural representations of secondary school students and university students of Ukraine.

3. To establish controversial aspects, which require additional attention in elaborating further intercultural educational policy for Ukrainian youth.

The questionnaire consisted of 44 questions (open, closed and semi-closed). To make the presentation of results more compact, we assorted the questions into 8 main groups covering 8 thematic blocks which represent basic intercultural ideas of Ukrainian youth to the Poles in particular and the problem of intercultural communication in general. The questions were intended to provide the research team with the following data:

- self-identification of respondents;

- attitude of Ukrainian youth to the Poles (various aspects);

- general ideas about causes of ethnic conflicts and ways of their positive solution;

- attitudes towards inter-ethnic marriages;

- attitudes towards the educational activity of ethnic minority (i.e. schools for a particular ethnic group in the country of their permanent residence) and other social activities;

- attitudes to possible prospects of moving abroad for a long-term period;

- attitude towards language;

- religious component in intercultural relations.

A separate block of questions made it possible to obtain personal information about the respondent (citizenship of a person, parents, education, age, gender, place of residence).

\section{Research Results}

\section{Students in the $3^{\text {rd }}$ and $4^{\text {th }}$ years of Ukrainian higher educational institutions}

Hereby, we present the data obtained as the result Ukrainian student youth's survey. Questions of the first block were aimed at defining respondents' national and ethnic self-identification status. The analyzed and summarized results of the 
survey showed that $1025(100 \%)$ of respondents considered themselves to be Ukrainians (Question: "What ethnic group do you consider yourself?"); 215 respondents $(21 \%)$ considered themselves to be village residents, $759(74 \%)$ do not associate themselves with rural residents, $51(5 \%)$ abstained from answering the question. 441 respondents $(43 \%)$ consider themselves as residents of the region whereas, $492(48 \%)$ do not think so, $92(9 \%)$ - refrained from answering the question.

At the same time, 72 respondents $(7 \%)$ acknowledge their Polish origin (they live in the western region of Ukraine, in the cities of L'viv, Rivne, Chernivtsi, Khmelnytsky). Moreover, respondents from cities of the eastern region, such as Mariupol, Zaporizhzhya, Melitopol, from the cities of the central region - Kyiv, Vinnytsya, Kremenchug and Lutsk (western region), do not consider themselves to be the Poles 100\%. With that 174 respondents (17\%) (from Mariupol, Khmelnytsky, Kamyanets-Podilsky, L'viv, Lutsk, Rivne, Kyiv and Vinnytsia) have relatives in Poland, and $246(24 \%)$ of those surveyed have relatives residing outside Ukraine.

964 respondents $(94 \%)$ gave an affirmative answer to their affiliation with the European community, $61(6 \%)$ - abstained from answering. 707 respondents $(69 \%)$ consider themselves to be the citizens of the world, 164 people $(16 \%)$ do not think so, $154(15 \%)$ abstained from answering the question.

In response to the question "Whom are you strongly connected with?" 984 respondents $(96 \%)$ indicated a strong relationship with their families, $41(4 \%)$ do not consider themselves related to the family. 984 respondents $(96 \%)$ demonstrate a sense of strong relationship with an ethnic group.

In this respect it is necessary to emphasize that 994 respondents $(97 \%)$ indicated that they were not related to the local community. At the same time, connection with the European community was recognized by 943 of respondents $(92 \%) .369$ of the surveyed $(36 \%)$ claimed they belong to the global community. $154(15 \%)$ gave a negative answer, $502(49 \%)$ - abstained from answering about affiliation with the global community.

According to the responses, representatives of Ukrainian nationality unconditionally dominate in the circle of respondents' friends and colleagues $(100 \%)$.

It is also important to emphasize that all the respondents $(100 \%)$ claimed that they do not take into account citizenship and confessional affiliation when choosing their friends and colleagues.

Questions of the second block were supposed to reflect the respondents' perceptions of similarities and differences between Ukrainians and Poles in various spheres of life. As for differences, $100 \%$ of respondents mentioned different religions; differences in the history of the people were mentioned by 984 respondents $(96 \%)$, differences in models of behavior - by 779 respondents $(76 \%)$, differences in culture and traditions - by 892 respondents $(87 \%)$.

902 respondents $(88 \%)$ indicate that the Poles and Ukrainians share similar political views; 615 respondents $(60 \%)$ believe they also have similar views on life 
in general. It should be noted that $100 \%$ of Ukrainian students surveyed do not see difficulties in relations between Poles and Ukrainians.

Regarding the relations that exist between Poles and Ukrainians in Ukraine, the answers of the respondents were distributed as follows: 502 respondents (49\%) are aware of the differences, but this does not affect their relationships; 195 respondents $(19 \%)$ believe that representatives of each of the two nationalities live in their own way; 164 respondents (16\%) said that people live in a single community in which there is no division or differences based on national (ethnic) principle; 123 respondents $(12 \%)$ believe that differences do exist, but mutual interests and sympathy are defining uniting factors; 41 respondents (4\%) believe that differences do not cause serious disputes or problems in the life of communities.

According to Ukrainian students, the Poles can learn sincerity, openness from Ukrainians, gain useful knowledge from the study of Ukrainian culture and traditions. And Ukrainians can learn from Poles the cultivation of purity, accuracy, respect for democracy and tolerance.

In total, 748 respondents (73\%) sympathize with the Poles and consider them to be close people; $113(11 \%)$ couldn't answer because they had no close encounters with the Poles; 92 respondents (9\%) expressed the opinion that there is no big difference between the Poles and Ukrainians, $72(7 \%)$ are indifferent to Poles.

Of all the respondents, $226(22 \%)$ are interested in the life and problems of Poles in Ukraine. They receive information from the Ukrainian media (81\%), from communication with friends and relatives.

It should be emphasized that $100 \%$ of respondents from cities such as Melitopol, Khmelnytsky, Lutsk, Rivne, Vinnytsia, Kremenchuk are not interested in the lives and problems of Poles in Ukraine.

Questions of the third block provided an opportunity to find out some general beliefs of respondents about interethnic relations, conflicts and possible ways of overcoming them. An important aspect is the fact that $100 \%$ of the respondents have not personally experienced any acts of hostility or discrimination against representatives of another nationality at all.

Questions of the fourth block provided an opportunity to define preferences of respondents in respect to marriage relations and interethnic marriages. 882 respondents $(86 \%)$ believe that the attitudes to mixed marriages in their region are positive. As for the choice of a partner for future family life, 502 respondents (49\%) consider ethnic origin and religious denomination of the partner as irrelevant; 400 respondents (39\%) want their life companion to be of Ukrainian origin, $92(9 \%)$ believe that partners in marriage may have different national origins, but belong to the same religion, 21 respondents (2\%) from the cities of Kamyanets-Podilsky, L'viv and Lutsk (Western region of Ukraine) would like their partners to be Poles.

The respondents defined the following drawbacks of marriages abroad: social isolation 441 (43\%), difficulties with employment 277 (27\%), problems caused by 
language barriers $174(17 \%)$, relatives' intolerance $103(10 \%)$, being rejected by the family of a spouse $31(3 \%)$.

Concerning the consent for a marriage of one's own child to a representative of another religious denomination, 533 respondents (52\%) gave positive answer, 420 $(41 \%)$ hesitated with the answer, $72(7 \%)$ wouldn't approve of such a marriage. Concerning the consent for a marriage of one's own child to a representative of another ethnic group $748(73 \%)$ respondents gave a positive answer, $226(22 \%)$ hesitated and $51(5 \%)$ said definite 'no'.

Questions of the fifth block helped to determine the attitude of respondents to various types of public organizations and schools of Polish minorities, as well as the level of respondents' involvement in social activity (i.e. membership in public organizations, their roles and activities in such organizations). 882 respondents $(86 \%)$ consider national minority schools as an efficient instrument for integrating people into a multicultural environment. According to 523 respondents (51\%) Polish minority schools play an important role in supporting traditions and memory of the historical past of the ethnic group. Also, they contribute to better integration of Poles into Ukrainian society said 502 respondents (49\%). Respondents believe that Polish schools aid the good relationships with the local community - 287 (28\%), promote the Polish language and contribute to improving language skills among students - 205 respondents (20\%), engage students in various school-based cultural events - $144(14 \%)$ and organize extracurricular cultural events - $103(10 \%)$.

The vast majority of respondents $(99 \%)$ positively evaluate the activities of Polish-language schools. 10 people $(1 \%)$ consider them as 'very good'.

All the respondents $(100 \%)$ believe that civic organizations, which unite representatives of national minorities, promote their integration and foster their mutual understanding and cooperation with the title nation. It is worth noting, that none of the surveyed take part in any Polish or Ukrainian non-governmental organizations.

The questions of the sixth block made it possible to discover respondents' beliefs, plans and expectations concerning perspectives of studying (or work) abroad. All respondents $(100 \%)$ claimed they had no previous experience of working abroad, 943 respondents $(92 \%)$ did not have any experience of learning abroad, but half of the respondents - 533 individuals $(52 \%)$ would like to study abroad, and 595 (58\%) would enjoy the opportunity to get job abroad.

For all the respondents $(100 \%)$ the main reason for leaving Ukraine was the 'desire to improve their financial situation'.

According to 646 respondents $(63 \%)$, they expect that residence in another country will bring them 'higher salary', 256 respondents $(25 \%)$ consider it as an opportunity to 'gain new skills and profession', for 113 respondents $(11 \%)$ such residence will contribute to their 'cultural development' and for 10 individuals $(1 \%)$ it means an opportunity of 'scientific development'. 
Questions of the seventh block made it possible to define the level of respondents' linguistic competency, primarily their foreign language skills. All respondents $(100 \%)$, use the Ukrainian language in everyday communication with their relatives, colleagues, friends and strangers. 1005 respondents (98\%) believe that they speak and write in Ukrainian perfectly well, whereas 21 persons (2\%) believe they fluently speak their native language, while occasional mistakes occur in writing.

The vast majority of respondents (984 people, 96\%) say they don't speak Polish, only 41 people $(4 \%)$ are fluent in Polish, but make occasional mistakes in writing (all of these respondents are residents of western region - L'viv, Chernivtsi and Rivne).

Regarding respondents' skills in other languages, we obtained the following data: 492 respondents (48\%) speak English, 144 people (14\%) speak German, and 72 individuals (7\%) speak French.

The questions of the eighth block provided information about respondents' religious beliefs and preferences. Since questions concerning religion were scattered on the questionnaire, contradictory results were obtained. 441 respondents $(43 \%)$ confirmed their belonging to a particular religious confession, $410(40 \%)$ were negative about this aspect, $174(17 \%)$ abstained from responding. At the same time 953 respondents (93\%) consider themselves to be faithful and deeply religious people, whereas 72 respondents (7\%) (from Mariupol, Zaporizhzhya and Kyiv) claim to be beyond religion and have very little involvement in church activities.

697 students (68\%) say that religion has a 'zero value' in choosing their friends. For 533 respondents $(52 \%)$ religion does not matter in their choice of a partner (future spouse), and $492(48 \%)$ would prefer to have a spouse of the same religious denomination. 1005 respondents $(98 \%)$ believe that in case of a mixed religion marriage each of spouses should be tolerant to religious views and beliefs of their partner. 461 respondents $(45 \%)$ have friends who belong to other religious denominations, 564 people $(55 \%)$ said that they don't have such friends. 964 respondents (94\%) don't see any reasonable reasons for avoiding contacts with people of a different denomination, while 62 of the surveyed $(6 \%)$ are trying to find friends within their religious confession.

871 respondents $(85 \%)$ consider Christianity as main religion, 154 people $(15 \%)$ said "all religions are equally important". For the majority of the respondents (953 people, 93\%) religion takes an important place in their lives, but it is not so important for 72 people (7\%). Only 482 respondents (47\%) attend church on the greatest religious days, $246(24 \%)$ - go to church once a month, 195 $(19 \%)$ - attend this institution once a week or more, $62(6 \%)$ - once a year, 31 $(3 \%)$ - do not attend it, and 10 people (1\%) refrained from answering this question. 


\section{Ukrainian pupils of the $10^{\text {th }}$ form of secondary education (secondary schools)}

Questioning of 10-grade students (300 people) of secondary educational institutions from 6 Ukrainian cities (Kyiv, Mariupol, Rivne, L'viv, KamyanetsPodilsky, and Vinnytsia) provided the researchers with the following data. Regarding their ethnic status (the first block of questions), all the respondents $(100 \%)$ consider themselves to be Ukrainians and Europeans; none of respondents considered themselves to be Poles. But $21(7 \%)$ of the respondents have some relatives in Poland, and $15(5 \%)$ have relatives in other countries.

Only 18 respondents $(6 \%)$ consider themselves to be rural residents, and 51 individuals $(17 \%)$ refrained from answering the question. 45 people $(15 \%)$ referred to themselves as residents of the region, 240 individuals $(80 \%)$ do not associate themselves with a particular region and 15 respondents $(5 \%)$ abstained from answering this question.

201 respondents $(67 \%)$ consider themselves to be the citizens of the world, 36 $(12 \%)$ - do not think so, $66(22 \%)$ - did not answer. 207 respondents $(69 \%)$ associate themselves with the global community, whereas $36(12 \%)$ - don't feel like that, and 57 people $(19 \%)$ have refrained from answering the question about their connection with the global community.

All respondents $(100 \%)$ recognize their strong relation to family, ethnic group, national community and European community. At the same time, 270 respondents $(90 \%)$ do not associate themselves with the local community.

All respondents $(100 \%)$ claim that Ukrainians predominate among their acquaintances and friends. Citizenship and religion are not important factors for the respondents when they choose their friends and colleagues.

The second block of questions was intended to identify common features and differences between Poles and Ukrainians. 273 respondents (91\%) mentioned different religions, $100 \%$ of respondents agreed on differences in the history of the two countries, and $180(60 \%)$ indicated differences in models of behavior of ethnic groups, $234(78 \%)$ admitted differences in culture, traditions.

As for the common aspects, 234 respondents $(78 \%)$ reported similarities in political views of the Poles and Ukrainians, and $210(70 \%)$ - similarity of their life values. All the respondents $(100 \%)$ do not see difficulties in the relationship between Poles and Ukrainians. 174 respondents (58\%) are aware of the differences between these ethnic groups, but it does not affect their relationship; 39 respondents $(13 \%)$ believe that representatives of each of the two nationalities live in their own way; $48(16 \%)$ say that they live in a community in which there is no ethic division; 39 respondents $(13 \%)$ believe that the division exists, but, in general, there is no serious problems, and their relations are determined by mutual interests and sympathy.

The majority of respondents (255 people or $85 \%$ ) sympathize with the Poles and consider them to be close, 39 individuals $(13 \%)$ were unable to answer this 
question as they had never had previous contacts with the Poles. Only 6 respondents $(2 \%)$ are indifferent to the Poles. Nevertheless 219 respondents $(73 \%)$ are not interested in the lives and problems of Poles in Ukraine. 81 respondents $(27 \%)$ (from Lviv and Kiev) are interested in the lives and problems of Poles in Ukraine. 294 respondents (98\%) receive some information from the Ukrainian media and only $6(2 \%)$ - from the Polish media.

The third block of questions. All respondents $(100 \%)$ claim that they have never faced any discrimination from representatives of another nationality or hostile attitude to them. Consequently, it is difficult for them to outline any approaches to preventing ethnic conflicts.

Answering the questions of the fourth block, the majority of respondents (291 or 97\%) noted that their choice of the partner doesn't depend on the national origin and religion, only 9 respondents $(3 \%)$ expressed their desire to have a spouse of the same nationality (Ukrainian). All respondents $(100 \%)$ are convinced that attitude towards mixed marriages in their region of Ukraine is rather positive. The main reasons causing difficulties in mixed marriages abroad may be social isolation (according to 201 respondents or 67\%), troubles with employment (39 people or 13\%), language barriers (54 people or $18 \%$ ), negative attitude of spouse's family (in the opinion of the 6 surveyed or $2 \%)$.

All school students see the possibility of integrating people of another nationality into a multicultural environment with the help of schools for national minorities (the fifth block of questions). According to 207 respondents $(69 \%)$, the school of the Polish minority promotes integration of its members into Ukrainian society. 93 respondents $(31 \%)$ are convinced that the Polish minority school helps to maintain traditions and memory of the historical past of the ethnic group. 69 respondents $(23 \%)$ believe that the Polish school helps to establish contacts with the local community and develop solid relationship with them, 96 people $(32 \%)$ believe such schools help to establish contacts with the local community. For 72 respondents $(24 \%)$ schools play great role in improving knowledge of the Polish language, for 51 respondents $(17 \%)$ schools are a platform for organizing various cultural events in which children are actively involved. 12 people $(4 \%)$ are convinced they provide additional opportunities for student's involvement in extracurricular cultural events.

All respondents $(100 \%)$ positively evaluate work of schools with Polish as the main teaching language and believe that civic organizations, which unite representatives of national minorities, contribute to integration and understanding of Poles with an ethnic majority. However, all the respondents $(100 \%)$ noted that they were not involved in the work of Polish or Ukrainian NGOs.

None of the respondents has ever worked abroad (according to the questions of the sixth block) and 294 respondents (98\%) have never studied abroad. At the same time, 168 respondents (56\%) would consider the opportunity of studying abroad, and $204(68 \%)$ would like to get job there. 
The desire to improve financial situation is one of the main reasons for leaving Ukraine said 285 respondents (95\%). 198 respondents (66\%) expect to get higher wages (in comparison to the level of income in Ukraine), 66 individuals (22\%) want to gain new professional skills or profession, 36 people (12\%) expect personal cultural development when going abroad.

All respondents $(100 \%)$ use Ukrainian for communicating with relatives, friends, strangers (according to questions of the seventh block). 279 (93\%) of them think that they speak and write in Ukrainian fluently, 21 respondents $(7 \%)$ acknowledged that they speak fluently whereas they make occasional mistakes while writing. The majority of respondents (279 people or 93\%) say it is difficult for them to speak and write in the Polish language. Only $9(3 \%)$ of them speak Polish fluently, but write with mistakes. 3\% of respondents (from western region L'viv and Rivne) said that they speak as well as write in Polish. 129 respondents (43\%) also indicate that they speak English, 63 (21\%) - German, and 21 (7\%) French.

Regarding religious beliefs (the eighth block of questions), 132 respondents $(44 \%)$ consider themselves to be deeply religious, 42 school student (14\%) indicated very low interest in religion, 126 respondents (42\%) refrained from answering. 153 respondents (51\%) agree that in case of a mixed marriage each of spouses has to be tolerant to their partner's religious beliefs and preferences. 147 respondents $(49 \%)$ refrained from answering the question.

6 respondents $(2 \%)$ would not object to their future child getting married to a person of another denomination, for 291 people $(97 \%)$ it was difficult to give a definite answer, 3 individuals (1\%) didn't not approve of such an idea. In respect to the question of hypothetical marriage of their own child to a person of another nationality 30 respondents $(10 \%)$ would not object to this decision; 264 respondents $(88 \%)$ hesitated with the answer, and 3 people $(1 \%)$ would be against it.

All respondents $(100 \%)$ do not take into account religious aspects when choosing their friends. 216 respondents $(72 \%)$ have friends who are representatives of other denominations. 213 respondents $(71 \%)$ recognize Christianity, 87 (29\%) people recognize all religions. At the same time religion and faith are important in the lives of all those surveyed. 165 respondents (55\%) mentioned that they attend church only during major religious holidays, for 57 people $(19 \%)$ it is a monthly event, 27 respondents $(9 \%)$ go to church once a week or more often, $48(16 \%)$ go there once a year, and $3(1 \%)$ said they do not go to church at all.

\section{Conclusions}

The analysis and interpretation of the results of the survey have provided the research team with sufficient empirical data for characterizing the current state of 
national awareness of Ukrainian youth, their beliefs and attitudes to the Poles as a separate nation.

From the obtained data it is possible to infer that all $(100 \%)$ respondents identify themselves as Ukrainians and prevailing majority (94\%) consider themselves to be the residents of the city, although this conclusion seems dubious, since the 2001 population census accounts for over $32 \%$ of the population to live in rural area ${ }^{6}$. An analysis of collected personal data about the survey participants indicates that almost $22 \%$ of them (or their parents) are from rural areas.

It is important to note that the vast majority of respondents associate themselves with the European community, which we consider as a consequence of intensification of European integration processes in various spheres of life of Ukrainian society after gaining independence. This indicator of personal selfidentification with the European community is $100 \%$ among school students, and $94 \%$ - among the older students. At that the older students' identification views traced the vagueness of their understanding of personal place in the globalized world, since $69 \%$ and $36 \%$ of answers were given to 2 similar questions on the questionnaire - about "identifying oneself as a citizen of the world" and about "personal connection with the global community". Due to the fact that 69\% of respondents consider themselves to be "the citizens of the world" and only $36 \%$ said they associate themselves with global community it is difficult to track a distinctive self-identification of Ukrainian students in the global world. Among school students the level of positive responses to these questions (67\% and 69\%) testifies an increase in the openness of Ukrainian youth.

Self-identification of respondents with Poles is insignificant, and is rather typical for residents of the western regions of Ukraine, territorially close to Poland (the highest percentage is 42\% (27 people) in L'viv, but compared to the total number of respondents, this is only $2.03 \%$ ). $17 \%$ of the surveyed students and $7 \%$ of school students have relatives in Poland.

At the same time, all Ukrainian respondents (100\%) do not observe difficulties in relations between Poles and Ukrainians. The majority of respondents consider different religions and differences in the history of ethnic groups to be the main differences between representatives of two nationalities.

All respondents $(100 \%)$ do not consider the ethnic origin and religion to be an important factor in choosing their friends or colleagues. This result shows the openness of young people in Ukraine to communication and intercultural interchange.

All respondents $(100 \%)$ believe that Polish-language schools and civic organizations help national minorities unite and contribute to their integration into the society of the country of residence, as well as foster building solid

6 Vidomosti perepysu naselennya Ukrainy v 2001 roci [Ukrainian population census data from 2001]. http://2001.ukrcensus.gov.u (In Ukrainian). 
relationship with other ethnic groups. However, 100\% of the respondents do not personally belong to either Ukrainian or Polish civic organizations. Thou we state a low level of social activity of young Ukrainians.

The Ukrainian youth consider moving to foreign countries as an opportunity of earning a good income, although all respondents have never had any work experience in another country. "Improving financial situation" is mentioned as the main reason for leaving Ukraine. In spite of the fact that, in general, only $8 \%$ of respondents have studied abroad, more than half of them would like to study abroad and / or get a job. Moreover, school students have showed higher interest in obtaining further education abroad $(56 \%$, whereas among students it is a bit lower - 52\%). $68 \%$ of school students would like to apply for employment in another country; among students this indicator is $58 \%$.

All respondents (100\%) indicated that they communicate with relatives, colleagues, friends, strangers in the Ukrainian language, although young people also use the Russian language in the eastern regions and in Kyiv. The survey has showed that, with the exception of the western regions of Ukraine (4\% in L'viv, Chernivtsi and Rivne), young Ukrainians do not speak Polish. It was also found that $69 \%$ of students and $71 \%$ of school students believe that they know a certain foreign language ( $49 \%$ of students and $43 \%$ of school students know English).

Information collected on the religious beliefs of young Ukrainian people reveal the inconsistency and ambiguity of their ideas, but show high level of their tolerance.

The results determined that a cognitive component of ethnic awareness is already formed in the mental picture of all respondents; it may be described as a rational-cognitive act ${ }^{7}$, which includes knowledge about particular ethnic groups, about history, customs, distinctive cultural features. According to the obtained results it is possible to conclude that Ukrainian student youth can be generally characterized as Pro-European, open to new influences and ideas, tolerant in terms of religious and ethnic dimensions. Nevertheless, their distinguishing negative features are social inertness and intercultural inaction.

Thos, there is a need for further development in the sphere of intercultural education of Ukrainian youth and shaping their experience in intercultural communication, which should be implemented on the basis of didactically and methodically appropriate principles and activities. These include teaching of the subject "Intercultural Communication" at school with an emphasis on ethnic and national characteristics of the residents of the neighboring states of Ukraine, in particular Poland; organizing extracurricular activities aimed at studying the specific features of representatives of other ethnic groups living in Ukraine;

Sknar, O. (2007). Osoblyvosti etnosotsialnykh uiavlen molodi. [The peculiarities of ethnic and social concepts of youth], Socialna psychologiya, 3, p. 59. (In Ukrainian). 
creating opportunities for cross-cultural youth group exchange events in order to familiarize the young Ukrainians with the culture and life of other countries and nations. We consider as an important step creating the dictionary of cultural literacy, similar to work of E. D. Hirsch ${ }^{8}$, but with an emphasis on the information related to the culture and customs of ethnic minorities that live in Ukraine and people of neighboring countries.

8 Hirsch E. D. - Jr., Kett, J. F.- Trefil, J. (2002). The new Dictionary of Cultural Literecy. $3^{\text {rd }}$ edition. Boston N.Y. 